REFLECTIONS:

NEUROLOGY AND THE

HUMANITIES

Section Editor

Michael H. Brooke, MD

\section{Reflections for June}

A Ketchum solstice at the 8-o'clock hole. Until then, fat lunkers would sit, like us, confident in the laws of nature, surrounded with August currents, conserving their energies.

Rich and I were sitting in lawn chairs in front of the 8-o'clock hole. It was hot, too damn hot. So hot that forest fires sent up distant orange clouds. We were barefoot, eight inches deep in river water, and well into some beers. Two remained in the deep waters. In a little over an hour they'd be gone.

Fly-fishermen came by, asking us to move. We'd stay, and given we were fishing it would be impolite to muscle in. Short answers, red-cheeked sunburns, a pile of empties on the beach, they probably concluded we were unenlightened to the ways of fishing the Big Wood River. Well, so be it.

One wearing chest-waders asked if we were using bait, demanded to see our hooks:

"It's fly-only water, barbs and bait aren't allowed ... You boys understand?"

Called us boys, blind to our gray hair, eyes cornerwrinkled and bagged below, hands spotted and freckled, knuckles scarred, places that wouldn't tan. Skins aged well beyond those of a boy. Turn those hands over and they're callused, lined with dirt, grease. And if you shook them, you'd know that grip was a fraction of what it could have been.

I reeled in, showed a prince nymph, hand tied, a hook without a barb. Rich stripped his line, jerky movements mistaken as voluntary, a slow silence passing. His beadhead trailed sediment clouds through shallows. He held it up; even with Rich's tremor, the hook was legal.

In return, Rich asked to see his Idaho license. He couldn't produce it, claimed he lived here, it was in his car and didn't need to show us anything.

"What's your name?"

"Why?"

"Poaching the Big Wood."

"Fishing without a license."

"Disturbing the peace."

Red faced, he stormed off, Rich called after him:

"Sometime you'll figure it out, son-actions have consequences."

Soon, once the sun falls below the range and the shadows ripen with blood hues, once the birds come out, and the bugs emerge, once the fire-smoke light turns cutthroat orange, the good stuff happens here.

\section{II: $\quad 7: 30 \mathrm{PM}$}

The lawn chairs were necessary. Rich couldn't stand long, let alone wade. I came because Rich needed help moving, because Rosie thought he might again be suicidal. Her words: "He needs a break; you make sure he doesn't do something stupid."

There's a short list of things to do in Sun Valley come summer; but for fighting fires and eating, most of the others were stupid. Rich and I came up with three more for the stupid list: drink, fish, and seduce heiresses. The first two we'd do fine, our appearances handicapped the latter.

"Ernest Hemingway killed himself here. Shotgun in the mouth ..."

"The 8-o'clock hole?"

"Ketchum ...."

"Why are you telling me this?"

"In Rehab, I was seeing double. Rosie got me books on CD. Hemingway. They don't read well out loud. At least the longer stuff doesn't. I liked it the best. You know sometimes you work hard at something you don't like and then you start to know it, and then suddenly_ bang — illumination."

I'm not sure I want to hear what's next. Bang indeed. Hemingway's father shot himself too.

"I wanted to see if he wrote about Ketchum, about The Big Wood.

"A fishing story?"

"Yep."

"Think about it — he writes about fishing and there's nothing about here? He lived in Ketchum, he killed himself yards from this river. Why would a man who loves fishing do that? This is prime water?"

"Beats me."

Rich's accident had one benefit - it killed off his stubborn, always right, unimaginative, and prejudiced side. He used to be a great match for my sister Rosie, who mirrored those traits. With his attentions now curbed, he made for better company, full of speculations, theories. He held no grudges, bore few regrets, even changed his political party. Rosie wanted him out 
of the house as much as possible; this new Rich terrified her. Not me, though; I didn't mind.

"You figure it out? Wasn't he just depressed?"

"More than that-he was sick."

"Papa was a drunk."

"Him and his wife were in a plane crash. 1954. He got burned, busted his neck and got into painkillers. On them you don't think straight."

"And he liked booze."

Rich held his can up.

"To Papa."

"Mmm."

"He was big-time overweight."

"Probably had sleep apnea."

"Got shock therapy a bunch, that must screw with your desire to fish."

"Or write."

"Never wrote quite as well after that plane crash."

"That last one, Old Man and the Sea ... Santiago catches the fish of his life, he's wrecked as he tries to bring the fish home. I liked that one."

"Sharks eat the fish, I remember that."

Dim Santiago memories of 9th-grade English with Mr. Stimple, a believer in speed-reading, rote grammar, and three-minute public speeches. I dreaded it, particularly the speaking. (Mine? One on "Death," the other "Christianity," both drawn from a binder filled with topics like "Bullfighting" or "Knots." What does a 15-year-old know about death or Christianity? Who talks for three minutes about knots?).

"You want to hear my theory?"

"I have a choice?"

"I figure he liked the big trophy fish. Tropical ones: marlin, sailfish. Once a trophy guy gets big fish, there's nothing more, only disappointment, nothing adds up. Plus he was a gear guy at heart, bait and boat. That's why he never wrote about here."

"As a fisherman, would you move to a place with no fish?"

"He was paid. Railroad company paid him to be here, publicity, put it on the map. He sold out, he didn't care. He knew his time was done."

Sirens were moving up North toward Galena summit, toward the Salmon River valley. Up in the National Forest groves of half-century trees were browned-out, infested with pine beetles, waiting for cinders to catch and put them to rest. It would be soon.

\section{III: $\quad 7: 45 \mathrm{PM}$}

Three winters back Rich was found in his garage, motorcycle running, pink-cheeked and passed out. He was brought to Seattle, to Harborview, later transferred to Virginia Mason where they dove him in their barochamber. He made it to Rehab. He came through it OK, could still think, maybe better in some ways, but was stuck with short jerks that would make him drop things and shake.

"Rich, there's something I've been wondering."

"What's that?"

"Why'd you try and kill yourself?"

\section{IV: $\quad 7: 50$ PM}

Background for you. My sister Rosie is a shorttempered, spindle-assed, unimaginative woman. Even without children, she's fond of strict rules and stupid foods (chicken nuggets, pretzels dipped in white chocolate, sheet cakes, Peeps). She gave criticism about as well as she couldn't take it. She's cute if you're not her brother or husband or if you don't hear her talk first. Despite these things, Rich and Rosie were once well-matched.

The night Rich got sick, they argued about "a nasty hair busting out of her chin mole." The longwinded way Rich put it, that giant gray hair represented everything he had come to loathe about Rosie: her nagging, her set views, her failure to see herself as others might.

I get Rich his last beer; mine too. He's animated now, leans forward in his chair, winds his line, ties on a Parachute Adams. His tremor helps cinch the knot. He clips the loose end with his teeth, squints, spits the end. He swears booze makes his tremor better.

Picture her saying this, she lights a cigarette, bouncing on her lips, smoke floats the words: "If the good Lord wants hair to sprout, by God I'll let it grow." (He does a pretty good Rosie impression, squeaky, high-pitched, irritating like an ungreased hinge).

He decided to take matters into his own hands. She'd fallen asleep eating again. The remains of her meatball sub partially covered the plush carpets. Dr. Phil was on TV in the background, Rosie on the couch, her breathing corrupted by fat apneas. In a lull, Rich got his fly scissors and snuck up with the mediocre skills of an overweight middle-aged suburban ninja.

"Bald dude on TV says 'change or stay miserable, your choice, change or stay miserable' and you know what? He's right."

Although Rich had Dr. Phil, Rosie had God on her side.

"I stepped on it, and you'd never know this, but a meatball's the same consistency as dog crap, you just slip a little, your balance gets thrown.”

Rich broke his fall by putting the scissor hand out. The blades grazed her neck, she awoke, saw the scissors, felt for where it hurt, and accused Rich of not just trying to cut her chin hair, but of cutting her sub apart so he could eat it. (Perhaps it's no wonder 
she was terrified of him, but what lunatic would sabotage a cold, carpet-fuzzed meatball with fly-tying scissors?) These perversions led to consequences, including a righteous shove that sent Rich onto the floor, onto what remained of the meatball sub, followed by a steam-eared nag about inadequacies.

He retreated to the garage, fired up his motorcycle, blue smoke, then clear. Revved it. She hated that-who wouldn't? The poorly silenced engine a floor below guaranteed Rosie would develop a blurry-eyed, hemisphere-pounding migraine. He'd done it before, rarely. He got distracted, sorting his fishing flies, puttering, and with the windows shut to keep December out, monoxides built up. Rich says there was no suicide attempt, just stupidity, a comeuppance for this chin-pube disaster.

\section{V: $\quad 7: 55 \mathrm{PM}$}

"It's hot. Too hot. Like the bad time. Hotter than

Cuba. Hotter than Pamplona. But not as hot as the bad time."

"Huh? What?"

"Hemingway. That's what it sounds like. There's good times. And then there's bad times. They cycle. And as a general rule the bad times are hot."

"It's hot now, that's for sure, and this isn't a bad time, excepting for that guy."

"The poacher?"

"Yeah."

"Maybe I got it the other way around; maybe the cold times are the bad times."
It was this distractible, mildly tremulous, half drunk, free-associating, meatball-cutting Rich that made, as far as I was concerned, for good company.

"What time is it?"

\section{VI: 8 o'clock}

A distant bell tolled in the hour. Rich downed the last of his beer. You could hear the ambulances heading south, faint and then louder, someone was hurt, smoke inhaled or burned or both. After they faded, you could hear the fish also rising. Loud smacks and slurps. Creatures of habit, like old men for their routines, their feeding hours, their small superstitions, their recollections half-true and half-fogged with imaginations no one can counter. Maybe Rich was telling the truth; maybe it was just stupidity. Or maybe understanding Hemingway's death was his therapy for more than a ridiculous argument about a chin hair.

I watched Rich roll cast right behind the medusa's head of an upturned stump. He mended to float close to the tangled mess. Some small flicker of movement caused him to set, and he was on to a nice fish, you could see that from the rod tip, a steady thump, the creature heading into the deep inkwell beneath that orange sky. The struggle continued, and finally turned, Rich played the fish into 8-inch waters and released it, still full of color and splash.

Rich was laughing — “There's my trophy." It was hot. Too damn hot. This was not a bad time. It was the good time. When the beers were cold and drunk, the talking done and the fish rising. 


\title{
Neurology
}

\author{
Reflections for June: The 8-o'clock hole \\ Michael John Doherty \\ Neurology 2010;74;1922-1924 \\ DOI 10.1212/WNL.0b013e3181e240e8
}

This information is current as of June 7, 2010

\section{Updated Information \& Services}

\section{Subspecialty Collections}

\section{Permissions \& Licensing}

\section{Reprints}

including high resolution figures, can be found at: http://n.neurology.org/content/74/23/1922.full

This article, along with others on similar topics, appears in the following collection(s):

\section{Depression}

http://n.neurology.org/cgi/collection/depression

Motor Control

http://n.neurology.org/cgi/collection/motor_control

Myoclonus; see Movement Disorders/myoclonus

http://n.neurology.org/cgi/collection/myoclonus_see_movement_disord ers-myoclonus

\section{Other toxicology}

http://n.neurology.org/cgi/collection/other_toxicology

Sleep apnea

http://n.neurology.org/cgi/collection/sleep_apnea

Information about reproducing this article in parts (figures,tables) or in its entirety can be found online at:

http://www.neurology.org/about/about_the_journal\#permissions

Information about ordering reprints can be found online: http://n.neurology.org/subscribers/advertise

Neurology ${ }^{\circledR}$ is the official journal of the American Academy of Neurology. Published continuously since 1951, it is now a weekly with 48 issues per year. Copyright . All rights reserved. Print ISSN: 0028-3878. Online ISSN: 1526-632X.

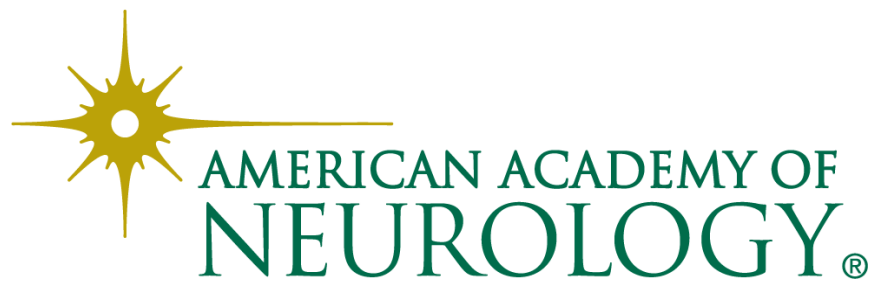

